\title{
Positron Emission Tomography Combined with Computed Tomography for Diagnosis of Synchronous Tumors
}

\author{
Pozitronová emisní tomografie kombinovaná s počítačovou \\ tomografií pro diagnózu synchronních nádorů
}

\author{
Garcheva M. ${ }^{\text {, }}$ Zlatareva D. ${ }^{2}$, Gocheva L. ${ }^{1}$ \\ ${ }^{1}$ Clinical Center of Nuclear Medicine, Radiotherapy, and Medical Oncology Medical University, Sofia, Bulgaria \\ ${ }^{2}$ Department of Diagnostic Imaging, Medical University, Sofia, Bulgaria
}

\begin{abstract}
Summary
Background: The hybrid method 18F-FDG PET/CT has been proven as a method of choice in oncology for diagnostics, staging, restaging of the tumor and evaluation of the therapeutic effect. The aim of the study was to determine the value of 18F-FDG PET/CT for detection of synchronous tumors and consequently the influence on the patients' management. Material and Methods: The examinations were performed on Discovery, GE Healthcare PET/CT using standard protocol. Among the patients, examined by 18F-FDG PET/CT for one year $(n=1408)$, unsuspected synchronous tumors were detected in 11 cases $(0.8 \%)$. Results: Five pulmonary carcinomas, four head and neck squamous cell carcinomas (HNSCC), one ovarian carcinoma and one tumor of the sigma were detected as second malignancies. The histology verification was done in five cases (all HNSCC and one sigma carcinoma). In one patient with ovarian carcinoma, histology was obtained after surgery. In the rest of patients, no verification was undertaken because of the patients' refusal and the advanced stage of the diseases, demanding systemic chemotherapy. Four patients (three with HNSCC and one with ovarian secondary malignancy) had favorable outcome during the nine-month follow-up. Conclusion: The hybrid method PET/CT, combining the metabolic and morphologic findings, can help detection of synchronous malignancies in a small percentage of cases, but with a positive influence on management of considerable part of such patients.
\end{abstract}

Key words

$\mathrm{PET} / \mathrm{CT}$ - synchronous tumors - multidisciplinary cancer care

\section{Souhrn}

Východiska: Hybridní metoda 18F-FDG PET/CT byla prokázána jako metoda volby v onkologii pro diagnostiku, staging, restaging nádorových onemocnění a vyhodnocení terapeutického účinku. Cílem této studie bylo zjistit hodnotu 18F-FDG PET/CT pro detekci synchronních nádorů a tedy i vliv na léčbu pacienta. Materiál a metody: Vyšetření byla provedena na Discovery, GE Healthcare PET/CT s použitím standardního protokolu. Mezi pacienty, vyšetřenými 18F-FDG PET/CT za jeden rok ( $n=1408)$, byly neočekávané synchronní nádory detekovány v 11 případech (0,8 \%). Výsledky: Jako sekundární malignity jsme detekovali pět plicních karcinomů, čtyři spinocelulární karcinomy hlavy a krku (head and neck squamous cell carcinomas - HNSCC), jeden ovariální karcinom a jeden nádor sigma. Ověření histologií bylo provedeno v pěti případech (všechny HNSCC a jeden karcinom sigma). U jednoho pacienta s karcinomem ovaria byla histologie získána po operaci. Ve zbytku pacientů nebyla provedena žádná kontrola, kvưli odmítnutí pacienta a pokročilému stadiu onemocnění, které vyžadovalo náročnou systémovou chemoterapii. Čtyři pacienti (tři s HNSCC a jedna se sekundární malignitou vaječníků) měli př́iznivý výsledek během devíti měsícủ sledování. Závěr: Hybridní metoda PET/CT, která kombinuje metabolické a morfologické nálezy, může pomoci detekovat synchronní malignity byt’ v malém procentu prípadů, ale s pozitivním vlivem na léčbu části těchto pacientů.
The authors declare they have no potential conflicts of interest concerning drugs, products, or services used in the study.

Autoři deklarují, že $v$ souvislosti s předmětem studie nemaji žádné komerční zájmy.

The Editorial Board declares that the manuscript met the ICMJE "uniform requirements" for biomedical papers.

Redakční rada potvrzuje, že rukopis práce splnil ICMJE kritéria pro publikace zasílané do biomedicínských časopisů.

\section{$\Xi^{\circ}$}

Assoc. Prof. Dr. Marina Garcheva Department of Nuclear Medicine Medical University Sofia

Zdrave Street 2

1431 Sofia

Bulgaria

e-mail: marina.garcheva@gmail.com

Submitted/Obdrženo: 6. 4. 2014

Accepted/Prijijato: 16. 4. 2014

Klíčová slova

PET/CT - synchronní tumory - multidisciplinární péče 


\section{Introduction}

18F-FDG PET/CT is widely used in oncology not only for determination of diagnosis, for staging and therapy planning but also for evaluation of therapeutic effect. Some of examined patients are known to have secondary malignancy. The aim of this study was to evaluate the rate of unexpected synchronous tumors, detected by PET/CT as incidental finding and to determine if it influences patients' management.

\section{Material and methods}

The examinations were performed on 16-slice PET/CT scanner Discovery GE Healthcare using F-18 FDG and standardized protocol of examination. The evaluation was generally done by visual assessment and semi quantitatively. PET/CT was interpreted by a specialist in nuclear medicine for PET examination and a radiologist for whole-body CT examination.

\section{Results}

Altogether, 1,408 patients were examined in one year; unsuspected syn-

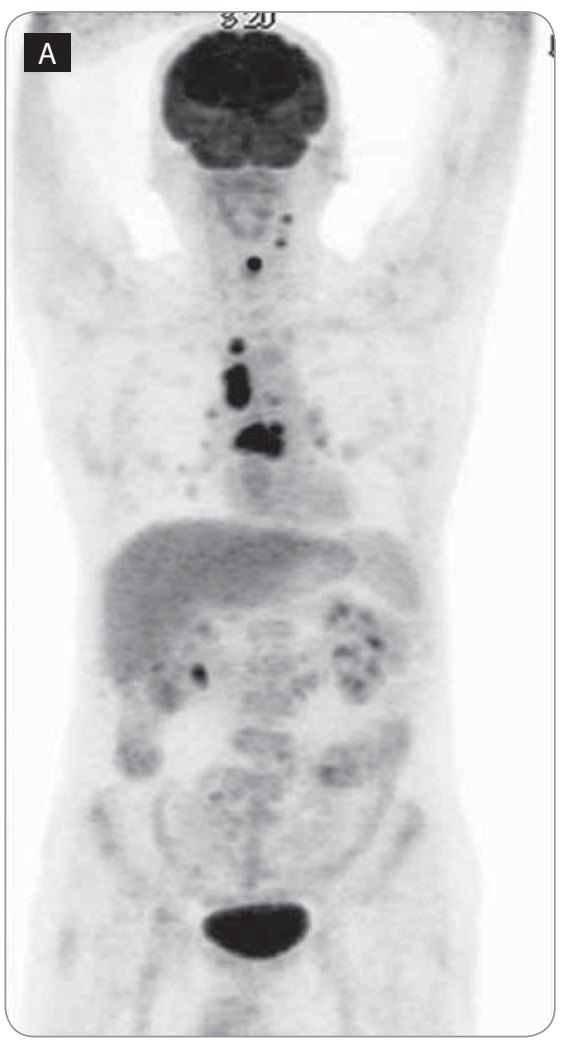

Fig. 1A. Coronal maximum-intensity-projection (MIP) PET. chronous tumors were detected in 11 of them $(0.8 \%)$ (three men and eight women, mean age $57.9 \pm 6$ years) We found the following secondary malignancy: lung tumors in five patients, head and neck tumors in four patients, ovarian carcinoma in one patient and colorectal tumor in one patient. A follow-up for nine months was done. From patients with lung carcinoma (primary
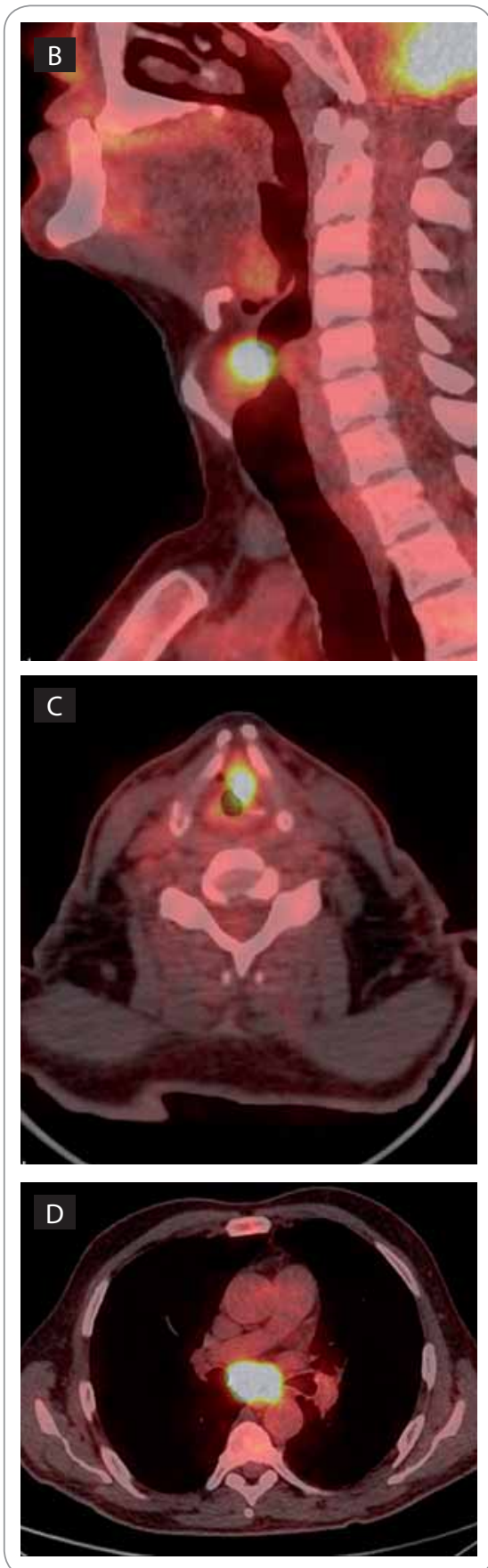

Fig. 1B-D. Sagittal and axial PET/CT image. or synchronous disease; $n=6$ ), four of patients had advanced disease at the time of examination, and two had progression during the follow-up. From patients with head and neck squamous cell carcinoma (HNSCC) as a synchronous tumor $(n=4)$, three had complete re-
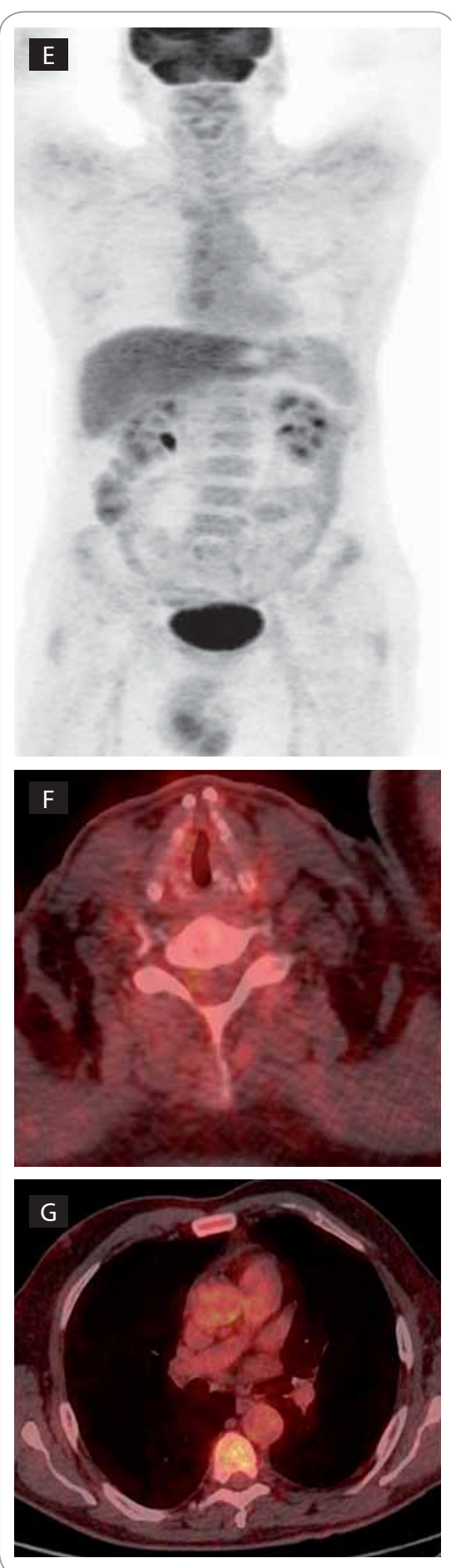

Fig. 1E-G. Eight months later on the follow-up PET/CT. 
sponse after therapy which was planned for both tumors. The patient with ovarian carcinoma synchronously detected with breast cancer had stable disease after change of management. In four patients, the management was changed in order to include surgery and radiotherapy, or surgery and chemotherapy for the synchronous tumor. The follow-up examinations demonstrated favorable outcome.

Case 1

A 65-year old male after extirpation of small-cell variant of neuroendocrine tumor (NET) in anorectal region

$\mathrm{PET} / \mathrm{CT}$ was indicated for restaging. Coronal maximum-intensity-projection (MIP) PET image (Fig. 1A), sagittal and axial PET/CT image demonstrate asymmetry of the larynx with increased FDG uptake in the left part SUV max 11.5 (Fig. 1B-D). Increased metabolism is present in enlarged neck, paratracheal, precarinal and subcarinal, aortopulmonal and both hilar lymphonodes. There was a suspicion of another primary tumor of the larynx with dissemination into the neck, mediastinal and hilar lymphonodes. The patient had histologic verification and both radiotherapy of the laryngeal carcinoma and chemotherapy were applied. Eight months later on the follow-up $\mathrm{PET} / \mathrm{CT}$, there was a complete response to the applied treatment (Fig. 1E-G).

\section{Case 2}

A 66-year old male with diagnosed cancer of the left lung after left upper lobectomy, recurrence, chemotherapy and treatment with cyber knife (Fig. 2A-E)

PET/CT helps to differentiate postoperative and radiation fibrosis of the left lung from recurrence what is impossible only on CT. Both adrenals appear normal. There is a liver metastasis and enlarged abdominal retroperitoneal and perigastral lymphonodes with increase FDG uptake. On PET/CT there is a suspicion of another primary tumor with origin of sigmoid colon which was histologically proven (Fig. 2E).

\section{Discussion}

Synchronous malignancies could change the patients' prognosis. According to

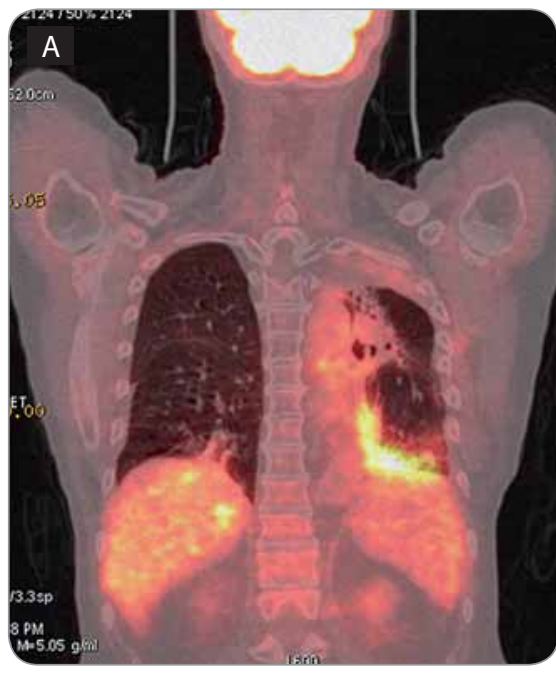

Fig. 2A. Coronal PET/CT.
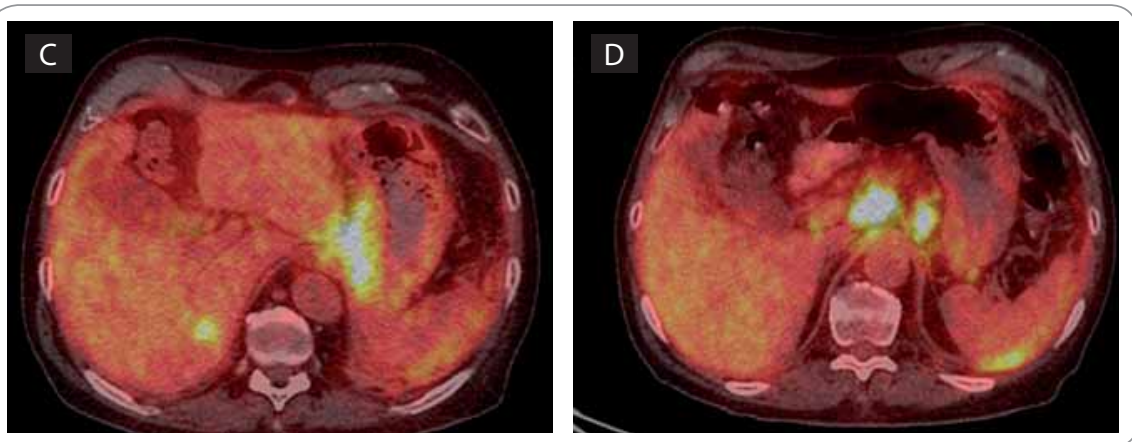

Fig. 2C, D. Axial PET/CT.

publications, synchronous tumors in the "aerodigestive area" are a well-known phenomenon that has been explained by the concept of „field cancerization“ [1-6]. The mucous epithelium of the head and neck, lung, and esophagus is exposed to common carcinogenic agents, such as tobacco and alcohol which promote carcinogenesis [7]. Published data about incidence of synchronous cancers concern mainly patients with esophageal cancer $[8,9]$. Frequently reported sites of synchronous tumors are head and neck, stomach, lung, and urinary bladder $[10,11]$. FDG/PET is reported to be good in detection of occult head and neck squamous cell carcinomas (HNSCC) and lung carcinomas, as were the most of synchronous malignancies detected in this study. In this study, they were frequently related to colorectal tumors (in 4/11 cases, $36 \%)$. The co-morbidity of lung carcinoma and breast carcinoma was also frequent, without relationship to the site of performed radiotherapy.

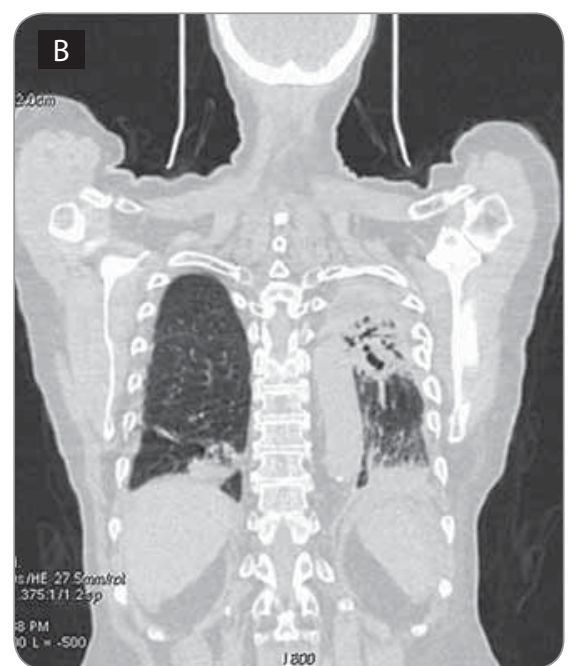

Fig. 2B. Coronal CT image (lung window).

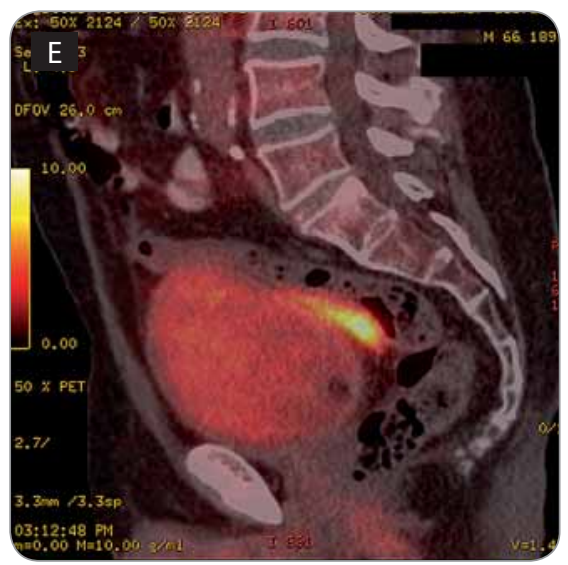

Fig. 2E. Sagittal PET/CT image.

According to literature, FDG-PET is more successful than conventional evaluation [12-19] for HNSCC. The sensitivity of PET was reported to be $10-60 \%$ [20], and high even for patients with negative physical and MRI examination [21]. In the early-stage of the disease, $80 \%$ of the patients have good prognosis after definitive locoregional 
treatment. For patients with advanced stage, the identification of the tumor site is important to guide the resection and to limit the extent of radiotherapy. This improves the locoregional control and overall survival $[22,23]$. In our patients with incidentally detected HNSCC, the follow-up demonstrated good results from the management of the synchronous tumor. For the ovarian cancer detected incidentally, the follow-up of nine months demonstrated also neither relapse, nor dissemination of the disease.

\section{Conclusion}

Knowing the pattern of dissemination of tumors, some of the detected lesions and pathological findings can be addressed to other primary tumor, what can significantly influence management of the patient. The rate of the detected synchronous malignancies is not high, but the careful interpretation, observation and histological confirmation can influence the patients' management and prognosis.

\section{References}

1. Poon RT, Law SY, Chu KM et al. Multiple primary cancers in esophageal squamous cell carcinoma: incidence and implications. Ann Thorac Surg 1998; 65(6): 1529-1534. 2. Van Rees BP, Cleton-Jansen AM, Cense HA et al. Molecular evidence of field cancerization in a patient with $7 \mathrm{tu}$ - mors of the aerodigestive tract. Hum Pathol 2000; 31(2): 269-271.

3. Wax MK, Myers LL, Gabalski EC et al. Positron emission tomography in the evaluation of synchronous lung lesions in patients with untreated head and neck cancer. Arch Otolaryngol Head Neck Surg 2002; 128(6): 703-707. 4. Keyes JW Jr, Chen MY, Watson NE Jr et al. FDG PET evaluation of head and neck cancer: value of imaging the thorax. Head Neck 2000; 22(2): 105-110.

5. Perlow A, Bui C, Shreve P et al. High incidence of ches malignancy detected by FDG PET in patients suspected of recurrent squamous cell carcinoma of the upper aerodigestive tract. J Comput Assist Tomogr 2004; 28(5): 704-709.

6. Quon A, Fischbein NJ, McDougal IR et al. Clinical role of 18 F-FDG PET/CT in the management of squamous cell carcinoma of the head and neck and thyroid carcinoma. J Nucl Med 2007: 48 (Suppl 1): 58S-67S.

7. Castellsague X, Quintana MJ, Martinez MC et al. The role of type of tobacco and type of alcoholic beverage in ora carcinogenesis. Int J Cancer 2004: 108(5): 741-749.

8. Kagei K, Hosokawa M, Shirato H et al. Efficacy of in tense screening and treatment for synchronous second primary cancers in patients with esophageal cancer. Jpn J Clin Oncol 2002; 32(4): 120-127.

9. Voormolen MH, Van Deelen RA, Tilanus HW et al. Esophageal carcinoma and multiple primary tumors. Dis Esophagus 1995; 8: 218-221.

10. Kumagai Y, Kawano T, Nakajima Y et al. Multiple primary cancers associated with esophageal carcinoma Surg Today 2001; 31(10): 872-876.

11. Nagasawa S, Onda M, Sasajima K et al. Multiple primary malignant neoplasms in patients with esophagea cancer. Dis Esophagus 2000; 13(3): 226-230.

12. Kole A, Nieweg O, Pruim J et al. Detection of unknown occult primary tumors using positron emission tomography Cancer 1998: 82(6): 1160-1166.

13. Johansen J, Eigtved A, Buchwald C et al. Implication of 18F-fluoro-2-deoxy-D-glucose positron emission tomography on management of carcinoma of unknown primary in the head and neck: a Danish cohort study. Laryngoscope 2002; 112(11): 2009-2014.
14. Jungehulsing $M$, Scheidhauer $K$, Damm $M$ et al. 2[18F]-fluoro-2-deoxy-D-glucose positron emission tomography is a sensitive tool for the detection of occult primary cancer (carcinoma of unknown primary syndrome) with head and neck lymph node manifestation. Otolaryngol Head Neck Surg 2000; 123(3): 294-301.

15. Aassar OS, Fischbein NJ, Caputo GR et al. Metastatic head and neck cancer: role and usefulness of FDG PET in locating occult primary tumors. Radiology 1999; 210(1): 177-181.

16. Rusthoven KE, Koshy M, Paulino AC. The role of fluorodeoxyglucose positron emission tomography in cervical lymph node metastases from an unknown primary tumor Cancer 2004: 101(11): 2641-2649.

17. Johansen J, Buus S, Loft A et al. Prospective study of 18FDG-PET in the detection and management of patients with lymph node metastases to the neck from an unknown primary tumor: results from the DAHANCA-13 study. Head Neck 2008; 30(4): 471-478.

18. Nassenstein K, Veit-Haibach P, Stergar H et al. Cervical lymph node metastases of unknown origin: primary tumor detection with whole-body positron emission tomography/computed tomography. Acta Radiol 2007; 48(10): 1101-1108.

19. Miller F, Karnad A, Eng T et al. Management of the unknown primary carcinoma: long-term follow-up on a negative PET scan and negative panendoscopy. Head Neck 2008; 30(1): 28-34.

20. Schoder $\mathrm{H}$, Yeung HW. Positron emission imaging of head and neck cancer, including thyroid carcinoma. Semin Nucl Med 2004; 34(3): 180-197.

21. Menda Y, Graham MM. Update on 18F-fluorodeoxyglucose/positron emission tomography and positron emission tomography/computed tomography imaging of squamous head and neck cancers. Semin Nucl Med 2005:35(4):214-219. 22. Cooper JS, Pajak TF, Forastiere AA et al. Postoperative concurrent radiotherapy and chemotherapy for high-risk squamous-cell carcinoma of the head and neck. N Engl J Med 2004; 350(19): 1937-1944.

23. Bernier J, Domenge C, Ozsahin M et al. Postoperative irradiation with or without concomitant chemotherapy for locally advanced head and neck cancer. N Engl J Med 2004; 350(19): 1945-1952.

\section{Informace z České onkologické společnosti}

Zápis ze schůze výboru České onkologické společnosti konané dne 17. 6. 2014 v Hradci Králové naleznete na www.linkos.cz. 